\title{
The effect of avocado seed powder (Persea americana Mill.) on the liver and kidney functions and meat quality of culled female quail (Coturnix coturnix japonica)
}

\author{
Elly Tugiyanti ${ }^{1}$, Ning Iriyanti² and Yosua Sujud Apriyanto ${ }^{2}$
}

1. Department of Animal Production, Faculty of Animal Science, University of Jenderal Soedirman, Purwokerto, Indonesia; 2. Department of Animal Nutrition, Faculty of Animal Science, University of Jenderal Soedirman, Purwokerto, Indonesia. Corresponding author: Elly Tugiyanti, e-mail: tugiyanti.elly@gmail.com Co-authors: NI: ningiriyanti@gmail.com, YSA: sujudyosua@yahoo.co.id Received: 31-05-2019, Accepted: 05-09-2019, Published online: 24-10-2019

doi: www.doi.org/10.14202/vetworld.2019.1608-1615 How to cite this article: Tugiyanti E, Iriyanti N, Apriyanto YS (2019) The effect of avocado seed powder (Persea americana Mill.) on the liver and kidney functions and meat quality of culled female quail (Coturnix coturnix japonica), Veterinary World, 12(10): 1608-1615.

\begin{abstract}
Background and Aim: High temperatures have a detrimental effect on quail performance, even disrupting the immune system and function of the internal organs. This research aimed to investigate the effectiveness of avocado seed powder supplements on meat quality and the liver and kidney functions of culled female quails.

Materials and Methods: A total of 100 six-month-old culled female quail were allotted to four dietary treatments, i.e., R0: Basal feed without avocado seed powder supplement and R1, R2, and R3 with basal feed $+3 \%, 6 \%$, and 9\% avocado seed powder supplement, respectively. The observed variables included meat quality (protein, fat, cholesterol and meat collagen, water holding capacity, and tenderness), liver function (liver weight, serum glutamic oxaloacetic transaminase [SGOT], and serum glutamic pyruvate transaminase [SGPT]), and kidney function (urea level, creatinine, uric acid, albumin, and glucose).
\end{abstract}

Results: Analysis of variance showed that avocado seed powder supplements significantly affected the level of SGOT, urea, creatinine, protein, fat, cholesterol, meat tenderness, and cooking loss. A non-significant effect was found on liver weight, SGPT, uric acid, albumin and glucose blood level, collagen, or water holding capacity level.

Conclusion: Avocado seed powder supplements improved meat quality as well as the liver and kidney functions of the culled female quail.

Keywords: cooking loss, flavonoid, natural antioxidant, poultry.

\section{Introduction}

Indonesian people rely on livestock products such as poultry to meet protein demand [1]. Quail is popular food-producing livestock as it starts laying eggs at 42-45 days of age. Female quails are bred for their eggs until they stop lying and culled for the meat [2]. Quail belongs to the homeothermic group of animals commonly prone to stress which decreases performance [3]. Meanwhile, the average temperature in Indonesia is relatively high, at $23-36^{\circ} \mathrm{C}$ [4]. Heat stress potentially increases blood pressure leading to a disruptive blood function in transporting oxygen, nutrition and metabolism residue, and impaired immune system, and organ functions $[5,6]$. This condition triggers damage in liver and kidney which maintain detoxification and secretion during heatstroke $[7,8]$. The liver also secretes enzymes including serum glutamic oxaloacetic transaminase (SGOT)

Copyright: Tugiyanti, et al. Open Access. This article is distributed under the terms of the Creative Commons Attribution 4.0 International License (http://creativecommons.org/licenses/ by/4.0/), which permits unrestricted use, distribution, and reproduction in any medium, provided you give appropriate credit to the original author(s) and the source, provide a link to the Creative Commons license, and indicate if changes were made. The Creative Commons Public Domain Dedication waiver (http:// creativecommons.org/publicdomain/zero/1.0/) applies to the data made available in this article, unless otherwise stated. and serum glutamic pyruvate transaminase (SGPT) into the blood, reflecting a normal function. Kidney damage can be identified by examining the creatinine and blood glucose levels the indicators of kidney performance [9].

Plant-based antioxidants are gaining popularity [10]. Phytochemicals from summer shield, herbs, and flax and fenugreek seeds can reduce plasma concentrations of triglyceride (TG), total cholesterol, high-density lipoprotein (HDL)-cholesterol, low-density lipoprotein (LDL)-cholesterol, glutamic oxaloacetic transaminase (GOT), glutamic pyruvic transaminase (GPT), glucose, and glutathione peroxidase; however, TGs, plasma HDL, luteinizing hormone secretion, follicle-stimulating hormone, and estradiol-17 $\beta$ may increase [11-13]. Avocado (Persea americana Mill.) grows well in tropical areas such as Indonesia. In 2017, there were 2,312,145 avocado trees in the country, producing 363,157 tons of fruit, $106,426 \mathrm{~kg}$ of which were for export [14]. A $0.3-0.5 \mathrm{~kg}$ fuerte avocado consists of $73.16 \pm 0.28 \%$ flesh, $15.02 \pm 0.08 \%$ seed, and $11.82 \pm 0.32 \%$ skin [15]. Only the flesh part is used and waste the seed which is a renowned source of carotenoids, minerals, phenolics, vitamins, fatty acids, saponin, tannin, flavonoid, glycoside, cyanogenic, alkaloid, phenol, and steroids $[16,17]$. The flavonoid in an avocado seed is 
a water-soluble phenolic compound with antioxidant properties [18]. The avocado seed has been reported to be rich in polyphenols, with antimicrobial and antioxidant activities [18]. It contains 150.6-265.75 mg ascorbic acid equivalents (AAE)/100 g antioxidant, $1.92 \mathrm{mg}$ quercetin $100 \mathrm{~g}$ flavonoid [19], and $>70 \%$ phenolic [17]. The phenolic compound in an avocado seed is $44.89 \mathrm{mg} / \mathrm{kg}$, higher than that in the leaves or flesh $[15,17,18]$. Herbal flavonoids activate appetite mechanisms in poultry, contribute to balancing the gastrointestinal microflora system, and exhibit anti-inflammatory and antioxidant effects. Phenol, flavonoids, and the scavenging ability of $P$. americana are positively correlated because flavonoids and phenol are antioxidants that inhibit lipid peroxidation, and reduce oxidative stress [19].

The natural antioxidants effects in avocado seed powder on quail have not been investigated elsewhere when this paper is being written. In general, research into the effect of natural antioxidants focus on increasing production, performance and immune levels, but the negative influence on the liver and kidney functions of quails has never been examined. This research aimed to investigate the effectiveness of avocado seed powder supplements on the liver and kidney functions and meat quality of culled female quail.

\section{Materials and Methods}

\section{Ethical approval}

The current study was carried out as a part of the Institute Research Project, and has been approved by the Research Committee.

\section{Animals and feed}

A total of 100 6-month-old culled female quail were raised at the research farm in Sokaraja Kulon Village, Banyumas District. Sokaraja Kulon is situated on the latitude $7^{\circ} 19^{\prime} 30^{\prime \prime} \mathrm{S}$ and longitude $108^{\circ} 39^{\prime} 20^{\prime \prime}$ $\mathrm{E}$ with hot and humid weather around $25 \cdot 6-34.2^{\circ} \mathrm{C}$. The culled female quails were randomly allocated into 20 cages with five quail per cage. Feed was given ad libitum twice a day at 7 am and $3 \mathrm{pm}$, and water was freely accessible. Quails' health status was controlled daily, and weight was measured on a weekly basis.

The feed for 10-week experiment was made of avocado seed powder, corn, rice bran, fishmeal, soy waste, palm oil, Topmix, salt, lysine, and methionine. The feed composition and formulation are shown in Table-1.

The culled quail was let in the 1-week preliminary before treatment. Avocado seed powder supplement was offered gradually across 4 days. Day 1 was $25 \%$ treatment feed $+75 \%$ commercial feed, Day 2 was $50 \%$ treatment feed $+50 \%$ commercial feed, Day 3 was $75 \%$ treatment feed $+25 \%$ commercial feed, and Day 4 onward $100 \%$ treatment feed. The avocado seed powder was mixed with basal feed according to the dietary treatment level; i.e., $0,3,6$, and $9 \%$ for 3 months, from November 2018 to January 2019.

The quails were weighed (163-168 g) before blood collection through venipuncture, the quails were slaughtered.

\section{Experimental design}

The research was conducted by a completely randomized design [20]. The four dietary treatments consisted of R0: Basal feed without avocado seed powder supplement, R1: Basal feed $+3 \%$ avocado seed powder supplement; R2: Basal feed $+6 \%$ avocado seed powder supplement; and R3: Basal feed $+9 \%$ avocado seed powder. Each treatment was repeated 5 times to achieve 20 treatment units, each with five quail. The observed variables included meat quality (protein,

Table-1: Treatment feed formulation.

\begin{tabular}{|c|c|c|c|c|}
\hline \multirow[t]{2}{*}{ Feed components } & \multicolumn{4}{|c|}{ Avocado seed powder supplement (\%) } \\
\hline & $\mathbf{0}$ & 3 & 6 & 9 \\
\hline Corn & 45 & 45 & 45 & 45 \\
\hline Rice bran & 27.50 & 27.50 & 27.50 & 27.50 \\
\hline Soy waste & 15 & 15 & 15 & 15 \\
\hline Fishmeal & 8 & 8 & 8 & 8 \\
\hline Avocado seed powder & 0 & 3 & 6 & 9 \\
\hline Oil palm & 1.20 & 1.20 & 1.20 & 1.20 \\
\hline Calcium carbonate $\left(\mathrm{CaCO}_{3}\right)$ & 2.50 & 2.50 & 2.50 & 2.50 \\
\hline Premix & 0.20 & 0.20 & 0.20 & 0.20 \\
\hline Lysine & 0.20 & 0.20 & 0.20 & 0.20 \\
\hline Methionine & 0.40 & 0.40 & 0.40 & 0.40 \\
\hline Total & 100 & 103 & 106 & 109 \\
\hline \multicolumn{5}{|l|}{ Nutrient content } \\
\hline CP (\%) & 18.28 & 18.59 & 18.90 & 19.21 \\
\hline ME (kcal/kg) & 2862.52 & 2969.63 & 3076.72 & 3183.85 \\
\hline CFat (\%) & 5.81 & 5.98 & 6.16 & 6.33 \\
\hline CF (\%) & 4.48 & 4.66 & 4.84 & 5.03 \\
\hline $\mathrm{Ca}(\%)$ & 2.76 & 2.78 & 2.80 & 2.82 \\
\hline$P(\%)$ & 1.25 & 1.25 & 1.26 & 1.27 \\
\hline Lysine (\%) & 1.12 & 1.12 & 1.12 & 1.12 \\
\hline Methionine (\%) & 0.71 & 0.71 & 0.71 & 0.71 \\
\hline
\end{tabular}

The result of proximate analysis in Laboratory of Livestock Nutrition, Animal Science Faculty, Jenderal Soedirman University and LPPT UGM (2019) 
fat, cholesterol, and meat collagen, water holding capacity, and tenderness), liver function (SGOT and SGPT), and kidney function (urea level, creatinine, and uric acid).

\section{Avocado seed powder production}

The avocado seed powder was made by soaking the avocado seed in water for $12 \mathrm{~h}$. It was then boiled, skinned, and thinly sliced for a quick sun-drying; subsequently, the dried seed was pulverized using a grinder. Proximate analysis showed that the avocado seed powder contained $11.83 \%$ water and $88.17 \%$ dry matter which consisted $5.77 \%$ crude protein, $7.33 \%$ crude fat, $3.14 \%$ fiber, $2.71 \%$ ash, $81.04 \%$ nitrogen-free extract, and $3881.13 \mathrm{kcal} / \mathrm{kg}$ metabolic energy. The phytochemical compounds in the avocado seed powder were $5.54 \%$ tannins, $7.59 \%$ saponins, and $5.41 \%$ flavonoids.

\section{Analysis of liver and kidney functions}

The blood samples were taken to observe the liver and kidney functions 1 day before the quails were slaughtered. The observed parameters included SGOT and SGPT enzymes, urea, creatinine, and uric acid, using an autoanalyzer (Reflotron [R] plus) [21]. One drop of blood $(30 \mu \mathrm{l})$ was smeared on a slide. Each parameter used different slides inserted into the autoanalyzer. The results were shown after a few minutes.

\section{Analysis of meat cholesterol}

Analysis of meat quality included meat cholesterol, protein, fat, collagen, tenderness, cooking loss, and water holding capacity. Cholesterol level was analyzed using the Liebermann-Burchard method [17]. Chloroform extract that contained cholesterol would react with acetic anhydride acid and thick sulfate acid and form a colored reaction.

\section{Analysis of meat quality}

The physical properties of the meat (tenderness, cooking loss, and water holding capacity), collagen, fat, water content, and protein level were analyzed using Foodscan ${ }^{\mathrm{TM}}$ with Near Infra-Red performance [22]. The samples were pulverized using a meat grinder, then weighed $\pm 100 \mathrm{~g}$ and placed in a sample cup ( $15 \mathrm{~cm}$ diameter) to the brim. At this stage, the computer was turned on and connected to the food scan. The food scan icon was pressed to activate the food scan program. The sample cup was inserted to the compartment and the "tool analysis" icon was turned on (to detect the average water content, protein, fat, and collagen in percentage unit $/ \%$ ). Each sample was coded, and the results were printed out.

\section{Statistical analysis}

The obtained data were subjected to analysis of variance, and any significant effects would be employed to an Honestly Significant Difference (HSD) test.

\section{Results}

\section{Liver function}

Liver weight and the SGPT and SGOT levels of the culled female quail given feed supplements with avocado seed powder were within the normal range (Table-2), similar to those in a report by Ardiani [23]. Therefore avocado seed powder supplement of up to $9 \%$ did not harm the liver function of the culled female quail.

Table-2 shows that supplementing avocado seed powder to culled female quails did not significantly affect liver weight or SGPT, but it highly significantly affected $(\mathrm{p}<0.01)$ the SGOT level. About 6\% supplement resulted in the lowest liver weight and SGPT level, but 3\% supplement displayed similar SGOT and lower SGPT to the control group. Therefore, supplementing feed with $6 \%$ avocado seed powder improved the liver function of the quail.

\section{Kidney function}

Quails fed with avocado seed powder supplement demonstrated normal kidney function with $5.45-10.27 \mathrm{mg} / \mathrm{dL}$ urea, $1.49-2.66 \mathrm{mg} / \mathrm{dL}$ creatinine, $3.60-4.32 \mathrm{mg} / \mathrm{dL}$ uric acid, $2.83-3.62 \mathrm{mg} / \mathrm{dL}$ albumin, and $89.80-1104.20 \mathrm{mg} / \mathrm{dL}$ glucose (Table-3). It was similar Ebile et al. [24] and Agina et al. [25]; i.e. $6.98-9.32 \mathrm{mg} / \mathrm{dL}$, $0.35-0.44 \mathrm{mg} / \mathrm{dL}$, and $1.08-5.47 \mathrm{mg} / \mathrm{dL}$ for normal urea, creatinine, and albumin, respectively. However, the uric acid was lower than those obtained by Agina et al. [25] at $16.02 \mathrm{mg} / \mathrm{dL}$ and glucose levels were lower than obtained by Scholtz et al. [26] at $14.4 \pm 0.6 \mathrm{mmol} / \mathrm{L}$.

Analysis of variance showed that the avocado seed powder supplement significantly affected $(p<0.01)$ urea and creatinine levels, but not uric acid, albumin, and glucose levels. The HSD test indicated that the control group had different results from the $3 \%, 6 \%$, and $9 \%$ supplement groups, as the flavonoids in avocado seed powder improved the health status of laboratory animals and prolong the shelf life of poultry products [27].

Table-2: The average level of SGPT and SGOT of culled female quail.

\begin{tabular}{|c|c|c|c|}
\hline Avocado seed powder ( $\%)$ & SGPT (mg/dL) & SGOT (mg/dL) & Liver weight (g) \\
\hline 0 & $31.78 \pm 4.74$ & $81.56 \pm 12.74^{a}$ & $4.04 \pm 0.73$ \\
\hline 3 & $24.98 \pm 7.35$ & $55.91 \pm 13.04^{\mathrm{ab}}$ & $3.79 \pm 0.37$ \\
\hline 6 & $25.49 \pm 8.41$ & $40.75 \pm 16.66^{b}$ & $3.75 \pm 0.26$ \\
\hline 9 & $29.31 \pm 10.85$ & $48.93 \pm 18.48^{b}$ & $3.99 \pm 0.63$ \\
\hline SEM & 1.41 & 4.45 & 0.11 \\
\hline $\mathrm{p}$ & 0.517 & $0.004 * *$ & 0.779 \\
\hline
\end{tabular}

a,bMeans bearing different superscripts in a column differ significant $(p<0.05)$. SEM: Standard error of mean. SGPT=Serum glutamic pyruvate transaminase, SGOT=Serum glutamic oxaloacetic transaminase 


\section{Meat quality of the culled quail}

The protein level of the quail that consumed feed supplemented with avocado seed powder was 21.38$23.56 \%$ (Table-4). It was higher than 17\% [28] but relatively similar to that of broiler quail, i.e., 19.91$22.72 \%$ [29] and 21.65\% [30]. Meat quality is assessed from its chemical and physical properties. Quails, chicken and beef share similar protein content $(21 \%)$, fat and cholesterol levels. However, tenderness is the ultimate quality of quail. Animal meat would get tougher and contained higher collagen as it gets older [31]. Analysis of variance showed that supplementing feed with avocado seed powder significantly $(p<0.01)$ increased the meat protein of the quails compared to those fed with basal feed.

The fat and cholesterol content of the quail fed on the avocado seed powder supplement was between 4.67-5.17\% and 24.56-39.68 mg/100 g, respectively (Table-4). Meat fat in this study was higher than $3.598-4.584 \%$ of the previous study [32], but the cholesterol level was lower than $10.00 \mu \mathrm{g} / \mathrm{g}$ [33]. Analysis of variance showed that the avocado seed powder significantly $(p<0.01)$ affected fat content and lowered cholesterol level $(\mathrm{p}<0.01)($ Table-4). The meat fat of the culled female quail fed on control feed $(0 \%)$ was not significantly different from that of the $6 \%$ and $9 \%$ supplementation. However the lowest, meat fat was observed in the 3\% supplement group.

The collagen level of the quail after avocado seed powder treatment was 1.86-1.89\% (Table-4), similar to 1.70-2.28\% with Azolla microphylla supplement [32]. Analysis of variance showed that avocado seed powder supplementation did not significantly affect the collagen level of the quail. About 3\% and 6\% avocado seed powder could reduce the collagen level.

\section{Discussion}

The liver is an organ that plays a crucial role in regulating most body metabolisms, such as carbohydrate, protein, and fat as well as synthesizing (excretion) of some protein parts, blood coagulation, urea, and other vital substances in the body. In addition, most cholesterol is produced in the liver [34]. It is where bile acid is formed and transported, and where steroid hormones (estrogen) are degraded. The essential function of the liver is to filter and discharge toxins in the body [35].

GOT is an enzyme in the cells of liver and other organs that will be discharged into the blood when the liver is damaged. GPT serum is the dominant enzyme in the liver. In SGOT and SGPT tests, the liver is considered damaged when the amount of enzyme in the plasma surpasses the standard. SGPT is a more sensitive indicator than SGOT because it is only present in hepatocyte and in low concentrations in other tissues.

Avocado seeds display antioxidant activity because they contain carotenoids, minerals, phenolics, vitamins, fatty acids, saponins, tannins, flavonoids, glycoside, alkaloids, phenols, and steroids [16,17]. These active compounds tend to reduce SGOT and SGPT, maintaining the liver weight. Avocado seeds are rich in Vitamin $\mathrm{C}$ and antioxidant by converting $\alpha$-ocopheroxyl radicals to $\alpha$-tocopherol. Flavonoids and phenols are reported to prevent liver damage [19].

Avocado seed powder contains active substances such as flavonoids, quercetin, vitamins, and minerals. Tanin inhibits fat absorption in the intestine, quercetin reduces accumulated fat molecules, and flavonoid and polyphenol increase lipase lipoprotein activity to prevent hyperlipidemia which triggers diseases such as liver damage. In other words, propolis can protect the internal organs, especially the liver [36]. Natural polyphenol is a plant-based secondary metabolite with a pharmacological effect on oxidative stress, lipid metabolism, insulin resistance, and inflammation, and encompasses the most crucial pathological process in the etiology of liver disease [35].

Table-3: The average level of urea, creatinine, and uric acid in culled female quail.

\begin{tabular}{|c|c|c|c|c|c|}
\hline $\begin{array}{l}\text { Avocado seed powder } \\
(\%)\end{array}$ & $\begin{array}{l}\text { Ureum } \\
\text { (mg/dL) }\end{array}$ & $\begin{array}{c}\text { Creatinine } \\
(\mathrm{mg} / \mathrm{dL})\end{array}$ & $\begin{array}{l}\text { Uric acid } \\
\text { ( } \mathrm{mg} / \mathrm{dL})\end{array}$ & $\begin{array}{l}\text { Albumin } \\
\text { (mg/dL) }\end{array}$ & $\begin{array}{l}\text { Glucose } \\
\text { (mg/dL) }\end{array}$ \\
\hline 0 & $10.27 \pm 2.01^{a}$ & $2.66 \pm 0.60^{a}$ & $3.60 \pm 0.89$ & $2.83 \pm 0.75$ & $93.40 \pm 15.07$ \\
\hline 3 & $6.24 \pm 1.19^{b}$ & $1.52 \pm 0.46^{b}$ & $4.32 \pm 1.12$ & $2.90 \pm 1.12$ & $99.80 \pm 10.18$ \\
\hline 6 & $6.19 \pm 1.43^{b}$ & $1.49 \pm 0.37^{b}$ & $4.24 \pm 1.21$ & $3.21 \pm 1.55$ & $89.8 \pm 13.14$ \\
\hline 9 & $5.45 \pm 2.34^{b}$ & $1.73 \pm 0.42^{b}$ & $4.28 \pm 1.14$ & $3.62 \pm 1.78$ & $104.20 \pm 15.54$ \\
\hline SEM & 0.21 & 0.14 & 1.42 & 0.29 & 3.08 \\
\hline $\mathrm{p}$ & $0.003 * *$ & $0.004 * *$ & 0.697 & 0.788 & 0.373 \\
\hline
\end{tabular}

a,bMeans bearing different superscripts in a column differ significant $(p<0.05)$. SEM: Standard error of mean

Table-4: Nutrient content of culled quail meat.

\begin{tabular}{|c|c|c|c|c|}
\hline Avocado seed powder ( $\%)$ & Protein (\%) & Fat $(\%)$ & Cholesterol (mg/100 g) & Collagen (\%) \\
\hline 0 & $21.38 \pm 0.23^{a}$ & $5.17 \pm 0.19^{a}$ & $39.68 \pm 4.70^{a}$ & $1.89 \pm 0.06$ \\
\hline 3 & $21.8 \pm 0.87^{a}$ & $4.67 \pm 0.08^{b}$ & $31.15 \pm 1.38^{b}$ & $1.89 \pm 0.15$ \\
\hline 6 & $23.56 \pm 0.36^{b}$ & $5.29 \pm 0.40^{a}$ & $29.16 \pm 3.03^{b c}$ & $1.86 \pm 0.08$ \\
\hline 9 & $22.72 \pm 1.18^{\mathrm{ab}}$ & $5.11 \pm 0.18^{\mathrm{ab}}$ & $24.56 \pm 1.78^{c}$ & $1.91 \pm 0.09$ \\
\hline SEM & 0.25 & 0.07 & 1.40 & 0.02 \\
\hline $\mathrm{p}$ & $0.002 * *$ & $0.006 * *$ & $0.000 * *$ & 0.826 \\
\hline
\end{tabular}

$a, b, c$ Means bearing different superscripts in a column differ significant $(p<0.05)$. SEM: Standard error of mean 
Polyphenol can suppress gene expression related to distressed cells and manage the cells involved in bile acid synthesis, elongated unsaturated fatty acid, and tetrahydrofolate synthesis [36]. Flavonoids comprise a diverse group of compounds found in various human foods. Flavonoid intake has been associated with several health benefits due to its potential antioxidant activity. Moreover, further research has revealed other activities such as anti-inflammatory and metabolic effects. Flavonoids display a multitude of activities; therefore, these compounds have been upgraded from antioxidant to bioactive compounds [37]. Some flavonoids, such as catechin, apigenin, and quercetin exhibit hepatoprotective activity and antihepatotoxic properties because the compounds inhibit lipid peroxide in the cell membrane. Quercetin exhibits antioxidant activity by inhibiting inflammation enzyme activities or by increasing glutathione synthesis [38]. Flavonoids are reported to stimulate the activity of RNA polymerase 1 DNA-dependent and biosynthesis of RNA and protein, resulting in DNA biosynthesis and cell proliferation, which lead to regeneration in the damaged part of the liver [23].

Urea and creatinine are chemical compounds to indicate normal kidney function, while creatinine is the result of endogen metabolism - the yield of phosphocreatine degradation to evaluate the glomerulus function. Urea is the final product of protein and amino acid catabolism in the liver distributed through intracellular and extracellular fluid into the blood and filtrated by the glomerulus. Uric acid is the product of purine nucleic acid catabolism, although the glomerulus filtrates the uric acid and secretes it by tubules distal, which is discharged in the feces [9]. Table-3 shows that the creatinine level fell from $2.66 \pm 0.60$ to $1.49 \pm 0.37 \mathrm{mg} / \mathrm{dL}$ due to flavonoid compounds. In degrading calcium oxalate crystals, flavonoid bonds with calcium to form a $\mathrm{Ca}$-flavonoid complex compound. Furthermore, flavonoid inhibits urolithiasis by disrupting the production of reactive oxygen species (ROS), thus preventing oxidative stress that leads to cell damage such as kidney obstruction [39].

In addition, the saponin, alkaloids, flavonoids, polyphenol, quercetin, and alcohol glucose of avocado seed powder contain amino acid (tryptophan and lysine), calcium, iron, tannin, sulfur, Vitamin A, Vitamin B, and Vitamin C, which can increase the glomerulus filtration rate, and inhibit the increase of urea and creatinine. Moreover, these compounds can inhibit urine crystallization and reduce lesion percentage in the kidney. Flavonoid lowers uric acid by inhibiting the action of oxidase xanthine enzyme in preventing or reducing the production of uric acid. Some flavonoids also serve as an antioxidant against superoxide radicals. Creatinine is the product of muscle metabolism; therefore, increasing creatinine levels signify kidney damage [40]. Furthermore, kidney failure is related to blood glucose level, as hyperglycemia plays a role in forming atherosclerosis, which narrows the lumen of the blood vessels and slows blood circulation rate down, leading to depletion of blood supply to the kidneys. It may cause a disturbance in the filtration process in the glomerulus and weaken kidney functions [39].

Albumin is a major protein in the blood that significantly determines the transport of physiological materials or body metabolites such as fatty acids, hormones, bilirubin, and external ligands, as well as the regulatory system of colloidal osmoses blood pressure. Avocados are loaded with antioxidants, phytochemicals, vitamins, minerals, fiber, and monounsaturated healthy fats [41]. Avocado seed flour did not affect blood albumin levels because the polyunsaturated fatty acids (PUFA) and monounsaturated fatty acid (MUFA) in avocado seed flour hydrolyzed by the enzyme lipase into free fatty acids (FFAs) in the blood could not quantitatively stimulate albumin synthesis in the liver. FFAs with the C4-C12 chain in blood plasma are always bound to albumin. It was in line with Murray et al. [42] that albumin is able to bind various types of ligand such as FFA.

In this study, blood glucose level was very low. As the quail gets mature, the erythrocytes count increases, but the blood glucose concentration decreases [43], presumably due to the unsaturated fatty acids, such as linoleic acid and oleic acid in the avocado seed flour. Linoleic acid includes unsaturated fatty acids with two double bonds PUFA, and oleic acid is an unsaturated fatty acid with one double/single bond MUFA. Diets high in unsaturated fatty acids in feed can increase the fluidity of cell membranes; therefore, the insulin receptors and glucose used by cells increase. The fatty acid composition of the lipid membrane affects the insulin action. Diets high in unsaturated fatty acids could increase membrane fluidity due to the increased insulin secretion and glucose used by cells [44]. Flavonoids increase glycolysis and glycogen pathways by suppressing the glycogenolysis and gluconeogenesis pathways, decrease glucose level [45].

The flavonoid in avocado contains high antioxidant properties [18], inhibits protein denaturation (the loss of structure and function of protein due to stress) and prevents the free radical formation in the body [46]. In addition, phytochemicals in avocado seed powder can increase acidic conditions in the pancreas, duodenum, and gallbladder, thereby increasing protease enzyme activity in breaking protein into amino acids [47]. Amino acids will be absorbed and converted into protein that consists of myofibrillar, sarcoplasmic, and connective tissue [48].

Avocado seed powder contains chemical compounds that are secondary metabolites, such as essential oil, alkaloids, flavonoids, saponins, and tannins, which can lower cholesterol levels. Flavonoid is an antioxidant that can lower fat and cholesterol in the blood, and saponin can lower cholesterol because it forms a complex bond that is insoluble in cholesterol. 
Table-5: The quality physical properties of meat.

\begin{tabular}{lccc}
\hline Avocado seed powder (\%) & Water holding capacity & Cooking loss & Tenderness $\left(\mathbf{k g} / \mathbf{c m}^{\mathbf{2}}\right)$ \\
\hline 0 & $36.21 \pm 0.94$ & $24.21 \pm 0.57^{\mathrm{a}}$ & $4.79 \pm 0.30^{\mathrm{a}}$ \\
3 & $36.63 \pm 0.70$ & $23.03 \pm 0.66^{\mathrm{ab}}$ & $4.04 \pm 0.10^{\mathrm{b}}$ \\
6 & $36.50 \pm 0.66$ & $23.43 \pm 0.50^{\mathrm{ab}}$ & $3.97 \pm 0.30^{\mathrm{b}}$ \\
9 & $35.88 \pm 1.28$ & $22.79 \pm 1.13^{\mathrm{b}}$ & $4.03 \pm 0.56^{\mathrm{b}}$ \\
SEM & 0.20 & 0.20 & 0.10 \\
p & 0.601 & 0.045 & 0.006 \\
\hline
\end{tabular}

a,bMeans bearing different superscripts in a column differ significant $(p<0.05)$. SEM: Standard error of mean

Several studies had shown that saponins from different sources exhibits lower serum cholesterol levels $[1,49]$. Besides acting as an antioxidant, polyphenol lowers cholesterol, LDL, and TG by improving the activity of lipase lipoprotein, resulting in a higher TG-enriched lipoprotein or a very-low-density lipoprotein (VLDL) and intermediate-density lipoprotein (IDL). The increasing HDL cholesterol level is partly due to the decreased VLDL level or the increased production of apolipoprotein (Apo) AI and Apo AII. A depleted LDL level may due to the increased VLDL and IDL clearance in the liver; therefore, LDL production declines [50]. Tannin could inhibit cholesterol by forming a reaction with mucosa protein and epithelial cells, which inhibits fat absorption [49].

Collagen is the most fibrous protein in animals, including quail; it contains about $33 \%$ of glycine and $21 \%$ of proline. Precursor collagen, trophagenagen, is a triple helix of three polypeptides chains, joined by hydrogen bonds. Avocado seed flour contains various active compounds, such as flavonoids and saponin, which display anti-inflammatory activity. Saponins inhibit the work of the cyclooxygenase enzyme by catalyzing the reaction of arachidonic acid to endoperoxidase. The inhibited cyclooxygenase and lipoxygenase enzymes shorten, the inflammatory reaction, and expedite the ability of transforming growth factor-B (TGF-B). TGF-B plays a role in stimulating fibroblast migration and proliferation. The fibroblast synthesizes collagen by forming new connective tissue, thus increasing the number of fibroblast cells and the collagen fibers subsequently [51].

Avocado flour supplementation did not affect collagen synthesis because the oxygen significantly affects the fiber preparation process, where the more oxygen presents, the more likely ROS is produced. ROS is crucial for physiology, but it grows in a pathological condition which could damage cells. In general, the mechanism of collagen reduction is correlated with the increased protease enzyme activity that reduces collagen production, increases collagen degradation, and accumulates the extracellular matrix of elastin [52].

Collagen fibers are the main fibers from connective tissue throughout the quail body. They are the main protein of the extracellular matrix, which contributes to the tenderness of meat. In line with Tugiyanti and Herijanto[32], the factors influencing meat tenderness are correlated with its composition, including fat cells between the meat fiber and collagen. The avocado seed has been reported to be rich in polyphenols, displaying antimicrobial, and antioxidant activities [18]. One seed contains 150.6-265.75 mg AAE/100 g antioxidant, and $1.92 \mathrm{mg}$ quercetin/100 g flavonoid [19], and $>70 \%$ phenolic [17]. The Vitamin C contained in avocado seed flour has a stimulating effect on increasing mRNA from collagen Types I and III. Vitamin C helps collagen synthesis and work as a cofactor in the hydroxylation process to activate prolyl hydroxylase to convert procollagen into collagen and lysis hydroxylase to crosslink to obtain a strong triple helix. In this study, avocado seed flour supplementation could influence collagen levels because the oxidation of Vitamin $\mathrm{C}$ with $\mathrm{Fe}^{2+}$ cofactors released many superoxide $\left(\mathrm{O}_{2}-\right)$ oxygen anions/radicals. When $\mathrm{O}_{2}$ - production is higher than the available oxygen, collagen synthesis increases. Avocado flour contains polyphenols and flavonoids exhibiting antioxidant activity, so $\mathrm{O}_{2}$ - can be neutralized and collagen synthesis remains stable [53].

Compared to a previous study [54], this research reported similar water holding capacity (35.88-36.63\% vs. $36.38-37.33 \%)$ but a lower cooking loss (22.79-25.21\% vs. 31.99-40.21\%). Analysis of variance showed that avocado seed powder supplementation significantly affected meat tenderness $(p<0.01)$ and cooking loss $(p<0.05)$, but not on water holding capacity (Table-5). Therefore, the meat fat was low and it slightly increased water holding capacity because of the intramuscular fat store [55]. The flavonoid effect of avocado seed powder could prevent meat fat oxidation due to oxidative stress [56-58]. Furthermore, the natural antioxidant actively promoted meat protein degradation, which made the meat more digestible, while maintaining physical meat properties as the indicators of meat quality by inhibiting the rate of oxidative damage.

\section{Conclusion}

Avocado seed powder supplement improves meat quality, and the liver and kidney functions of culled female quail.

\section{Authors' Contributions}

YSA performed the experiment under the supervision of ET and NI. NI designed the concept, and analyzed, and interpreted the data. ET did the proofreading, guided the preparation, and finalized the manuscript for publication. All the authors read and approved the final manuscript. 


\section{Acknowledgments}

The authors would like to thank Research and Community Service Institute of Jenderal Soedirman University for the financial support through Applied Research 2018.

\section{Competing Interests} interests.

The authors declare that they have no competing

\section{Publisher's Note}

Veterinary World remains neutral with regard to jurisdictional claims in published institutional affiliation.

\section{References}

1. Priyono, P. (2018) Perspective on the production availability of animal protein sources from livestock in Indonesia. WARTAZOA, 28(1): 23-32.

2. Maknun, L., Kismiati, S. and Mangisah, I. (2015) Quail hatchery waste powder on the performance of quails (Coturnix coturnix japonica). J. Ilmu Ilmu Peternakan, 25(3): 53-58.

3. Hanafy, A.M. and Khalil, H.A. (2015) Influence of chronic dexamethasone administration on reproductive parameters and semen traits in male of Japanese quail. Asian J. Poult. Sci., 9(4): 223-232.

4. BMKG. (2018) Prakiraan Cuaca Indonesia. Available from: www.bmkg.go.id. Last accessed on 27-06-2018.

5. Lara, L.J. and Rostagno, M.H. (2013) Review: Impact of heat stress on poultry production. Animals, 3(2): 356-366.

6. Tamzil, M.H. (2014) Heat stress on poultry: Metabolism, effects and efforts to overcome. Wartazoa, 24(2): 57-66.

7. Steven, M. and Oltean, S. (2018) Assessment of kidney function in mouse models of glomerular disease. J. Vis. Exp., e57764(136): 1-10.

8. Tamzil, M.H., Noor, R.R., Hardjosworo, P.S., Manalu, W. and Sumantri, C. (2014) Hematological response of chickens with different heat shock protein 70 genotypes to acute heat stress. Int. J. Poult. Sci., 13(1): 14-20.

9. Finn, W.F. (2016) Kidney disease and gout: The role of the innate immune system. Open Urol. Nephrol. J., 9(1:M3): $12-21$.

10. Tugiyanti, E., Rosidi, R. and Anam, A.K. (2017) The effect of breadfruit leaves (Artocarpus altilis) flour on eggs production and eggs quality of Japanese quail (Coturnixcoturnix japonica). Agripet, 17(2): 121-131.

11. Saleh, A.A., Ijiri, D. and Ohtsuka, A. (2014) Effect of summer shield supplementation on growth performance, nutrient utilization, and plasma lipid profiles in broiler chickens. Vet. Med., 59(11): 536-542.

12. Saleh, A.A., Ebeld, T.A. and Abudabos, A.M. (2018) Effect of dietary phytogenics (herbal mixture) supplementation on growth performance, nutrient utilization, antioxidative properties, and immune response in broilers. Environ. Sci. Pollut. Res., 25(15): 14606-14613.

13. Saleh, A.A., Ahmed, E.A. and Ebeid, T.A. (2019) The impact pf phytoestrogen sources supplementation on reproductive performance, plasma profile, yolk fatty acids and atioxidative status in aged laying hens. Reprod. Domest. Anim., 54(6): 846-854.

14. Statistik, B.P. (2017) Statistics of Annual Fruit and Vegetable Plants Indonesia 2017. In: Indonesia S-doHSB-S, editor.www.bps.go.id. Last accessed on 27-06-2018.

15. Marsigit, W. (2016) Morphometric characteristics, proportion, total phenol content and profil phenolics of avocado (Persea americana, Mill) pulp, seed and peel variety of ijo panjang and ijo bundar. J Agroind., 6(1): 18-27.

16. Tabeshpour, J., Razavi, B.M. and Hosseinzadeh, H. (2017)
Effect of avocado (Persea americana) on metabolic syndrome: A comprehensive systematic. Phytother. Res., 31(6): 819-837.

17. Anggraeny, D., Inneke, F.M. R., Gregoria, S.S.D. and Pipih, S. (2017) Antioxidant's activity of avocado (Persea americana Mill.) seeds extract coating by nanochitosan. $J$. Ilmu Teknol. Pangan, 5(2): 6-11.

18. Antasionasti, I., Riyanto, S. and Rohman, A. (2017) Antioxidant activities and phenolics contents of avocado (Persea americana Mill.) peel in vitro. Res. J. Med. Plants, 11(2): 55-56.

19. Folasade, O.A., Olaide, R.A. and Olufemi, T.A. (2016) Antioxidant properties of Persea americana M. seed as affected by different extraction solvent. J. Adv. Food Sci. Technol., 3(2): 101-106.

20. Steel, G.D. and Torrie, J.H.(2001) Principles and Procedure of Statistics. A Biometrical Approach. Mc Graw-Hill Inc, New York

21. Berata, I.K., Susari, N.N.W., Kardena, I.K. and Ariana, I.N.T. (2016) Blood lead contamination in Bali cattle reared in the area of final disposal of denpasar. Indonesian Vet. J., 17(4): 641-646.

22. Bekhit, A.E.A.(2017) advances in meat processing technology. CRC Press-Taylor and Francis Group, London. p586.

23. Ardiani, N. (2017) The effectiveness of red yeast rice antioxidant on performance of Japanese quail induced oxidative stress through dexamethasone administration. Thesis. Agricultural University, Bogor, Indonesia.

24. Ebile, D.A., Raphaël, K.J., Wilfried, E.N.L., Joël, P.M.H., Gildas, N.D., Ruben, N.T., Hervé, M.K. and Florence, F.A. (2018) Growth performance, gut microbiota and haemato-biochemical profile of quails fed diet supplemented with graded levels of D. glomerata fruit powder. Anim. Vet. Sci., 6(5): 80-87.

25. Agina, O.A., Ezema, W.S. and Iwuoha, E.M. (2017) The haematology and serum biochemistry profile of adult Japanese quail (Coturnix coturnix japonica). Notulae Sci. Biol., 9(1): 67-72.

26. Scholtz, N., Halle, I., Flachowsky, G. and Sauerwein, H. (2009) Serum chemistry reference values in adult Japanese quail (Coturnix coturnix japonica) including sex-related differences. Poult. Sci., 88(6): 1186-1190.

27. Iskender, H., Yenice, G., Dokumacioglu, E., Kaynar, O., Hayirli, A. and Kaya, A. (2016) The effects of dietary flavonoid supplementation on the antioxidant status of laying hens. Braz. J. Poult. Sci., 18(4): 663-668.

28. Boni, I., Nurul, H. and Noryati, I. (2010) Comparison of meat quality characteristics between young and spent quails. Int. Food Res. J., 17(3): 661-666.

29. Slobodyanyuk, N. (2014) Nutritional and biological value of quail meat with feed-staff usage with different protein levels. Sci. J. Sci. Rise, 3(3): 68-71.

30. Khalifa AH, Omar, M.B., Hussein, S.M. and Abdel-Mbdy, H.E. (2016) Nutritional value of farmed and wild quail meats. Assiut J. Agric. Sci., 47(6-1): 58-71.

31. Tugiyanti, E., Yuwanta, T., Zuprizal and Rusman (2013) Improving performance, meat quality and muscle fiber microstructure of native Indonesian Muscovy duck through feed protein and metabolizable energy. Int. J. Poult. Sci, 12(11): 653-659.

32. Tugiyanti, E. and Herijanto, S. (2018) Carcass production and meat tenderness characteristics of culled quail fed with Azolla microphylla flour supplemented basal feed. Bul. Peternakan, 42(4): 315-321.

33. Suciningtyas, C.P., Rachmat, W. and Hendi, S. (2016) Effect of Ration Containing Noni Fruit Powder (Morinda citrifolia L.) on Quail Egg (Coturnix coturnix japonica) Cholesterol and Yolk Colour Index. Fakultas Peternakan, Universitas Padjadjaran Bandung.

34. Milic, S., Ivana, M., Lidija, O., Edita, D., Nada, S.C., Davor,S., Miljenko, K. and Smiljana, R. (2016) The role of iron and iron overload in chronic liver disease. Med. Sci. 
Monit., 22: 2144-2215.

35. Li, S., Tan, H.Y., Ning, W., Fan, C., Ming, H. and Yibin F. (2018) Review article: The potential and action mechanism of polyphenols in the treatment of liver diseases. Oxid. Med. Cell. Longev., 2018(ID 8394818): 25.

36. Van De Wier, B., Koek, G.H., Bast, A. and Haenen, G.R.M. (2017) The potential of flavonoids in the treatment of non-alcoholic fatty liver disease. Crit. Rev. Food Sci. Nutr., 57(4): 834-855.

37. Tungmunnithum, D., Areeya, T., Apinan, P. and Aujana, Y. (2018) Flavonoids and other phenolic compounds from medicinal plants for pharmaceutical and medical aspects: An overview. Medicines, 5(3): 1-16.

38. Widiasari, S. (2018) Inhibition angiotensin converting enzyme mechanism by flavonoid in hypertension. Collab. Med. J., 1(2): 30-44.

39. Anshar, A.R., Muhammad, A.B. and Dini, K.I. (2018) The effect of avocado to the profile of blood urea nitrogen (BUN) and creatinine in rats (Rattus norvegicus) induces with meloxicam. J. Indonesia Vet. Res., 2(1): 1-7.

40. Madyastuti, R. (2010) Pengarun Infusum Daun Alpukat (Persea americana Mill) Dalam Menghambat Kristal Urin Yang Diinduksikan Etilen Glikol Pada Tikus Putih Jantan [Tesis].

41. Henry, L.N., Upendo, Y.M. and Catherine, C.K.K. (2015) Nutritional efficacy of avocado seeds. Glob. J. Food Sci. Technol., 3(5): 192-196.

42. Murray, R.K., Granner, D.K., Mayes, P.A. and Rodwell, V.W. (2009) Biokimia Harper. $27^{\text {th }}$ ed. Penerbit Buku Kedokteran EGC, Jakarta. p174-181.

43. Raji, K., Surendranathan, K.P. and Philomina, P.T. (2000) Effect of age and sex on the blood sugar profile in Japanese quail (Coturnix coturnix japonica). J. Vet. Anim. Sci., 31:53-56.

44. Sizer, F.S. and Whitney, E. (2007) Nutrition Concepts and Controversies. Thompson Wadsworth, Belmont, USA.

45. Anjani, P.P., Shelly, A. and Tri, D.W. (2015) Effect of addition of fragant pandannus and cinnamon in herbal tea by peel of snake fruit for diabetic. J. Pangan Agroind., 3(1): 203-214.

46. Wildman, R.E.C. (2001) Handbook of Nutraceuticals dan Functional Food. CRC Press, Boca Raton.

47. Delles, R.M., Xiong, Y.L., True, A.D., Ao, T. and Dawson, K.A. (2014) Dietary antioxidant supplementation enhances lipid and protein oxidative stability of chicken broiler meat through promotion of antioxidant enzyme activity. Poult. Sci., 93(6): 1561-1570.

48. Akbarian, A., Michiels, J., Degroote, J., Majdeddin, M., Golian, A. and De Smet, S. (2016) Association between heat stress and oxidative stress in poultry; mitochondrial dysfunction and dietary interventions with phytochemicals. J. Anim. Sci. Biotechnol., 7(37): 2-14.

49. Chaudhary, S.K., Rokade, J.J., Aderao, G.N., Singh, A., Gopi, M., Mishra, A. and Raje, K. (2018) Saponin in poultry and monogastric animals: A review. Int. J. Curr. Microbiol. Appl. Sci., 7(7): 3218-3225.

50. Nasution, A.Y., Prasetyo, A. and Putu, A.S. (2015) Effect of propolis extract on SGOT (serum glutamic oxaloacetic transaminase) and SGPT (serum glutamic pyruvic transaminase) Level of Wistar rats (Rattus norvegicus) with high fat diet. Majalah Kesehatan FKUB, 2(3): 120-126.

51. Zhou, S., Salisbury, J., Preedy, V.R., Emery, P.W. (2013) Increased collagen synthesis rate during wound healing in muscle. PLoS One, 8(3): e58324.

52. Panchatcharam, M., Sumitra, M., Vinaya, S.G. and Lonchin, S. (2006) Curcumin improves wound healing by modulating collagen and decreasing reactive oxygen species. Mol. Cell. Biochem., 290(1-2): 87-96.

53. Pakaya, D. (2014) Peranan Vitamin C pada kulit. Med. Tadulako J. Ilmiah Kedokt., 1(2): 45-54.

54. Hakim, I. (2017) The Effect of Age at Slaughter on Carcass Production and Meat Quality of Male Quails. The Faculty of Agroindustry, Department of Animal Science, Mercu Buana University.

55. Soeparno. (2015) Meat Science and Technology. $2^{\text {nd }}$ ed. Gadjah Mada University Press, Yogyakarta.

56. Qadir, M.A., Syeda, K.S., Asad, B., Adil, M. and Shabnam, S. (2017) Evaluation of phenolic compounds and antioxidant and antimicrobial activities of some common herbs. Int. J. Anal. Chem., 2017(ID 3475738): 1-6.

57. Mardigan, L.P., dos Santos, V.J., da Silva, P.T., Visentainer, J.V., Gomes, S.T.M. and Matsushita, M. (2018) Investigation of bioactive compounds from various avocado varieties (Persea americana Miller). Food Sci. Technol., 39(1): 1-7.

58. Feliana, K., Mursiti, S. and Harjono, H. (2018) Isolasi dan elusidasi senyawa flavonoid dari biji alpukat (Persea americana Mill.). Indonesian J. Chem. Sci., 7(2): 153-159. 